\title{
Power and powerlessness Alfred Schutz's theory of relevance and its possible impact on a sociological analysis of power
}

\author{
Poder e desempoderamento \\ A teoria da relevância de Alfred Schutz e seu possível impacto \\ na análise sociológica do poder
}

Andreas Goettlich*

\begin{abstract}
After demonstrating that there is a certain deficit within the existing sociological reflection on power, this article discusses the possible benefit of consulting Alfred Schutz's theory of relevance for the study of power relations. Especially, Schutz's distinction between "intrinsic" and "imposed" relevances is reconsidered at length. The thesis claims that an application of Schutz's concepts can be of some original use, particularly in exploring the perspective of those subject to power, however this application calls for some theoretical revision.
\end{abstract}

Keywords: power, powerlessness, (theory of) relevance, Alfred Schutz

Resumo: Após demonstrar que há um certo déficit na reflexão sociológica disponível sobre poder, o artigo discute o possível benefício de consultar a teoria da relevância de Alfred Schutz para o estudo de relações de poder. Em especial, a distinção de Schutz entre relevância "intrínseca" e "imposta" é reconsiderada detidamente. A tese sustenta que uma adoção dos conceitos de Schutz podem ser originais, particularmente ao explorer a perspectiva daqueles sujeitos de poder, entretanto, esta aplicação exige alguma revisão teórica.

Palavras-chave: poder, ausência de poder, (teoria da) relevância, Alfred Schutz

* Andreas Goettlich works as a research fellow at the University of Konstanz, Germany. His topics of research fall within the scope of the sociology of knowledge, protosociology, the sociology of morality, and the sociology of corruption.<andreas.goettlich@uni-konstanz.de>

\begin{tabular}{|l|l|l|l|l|l|}
\hline Civitas & Porto Alegre & v. 11 & n. 3 & p. 491-508 & set.-dez. 2011 \\
\hline
\end{tabular}




\section{Introduction: outlining the problem}

Power is omnipresent - this fundamental statement not only applies to social reality but also to its study within sociological theory. When thinking about social relationships, one cannot ignore the importance of power, which has, consequently, been one of the central subjects for social scientists of all types since the dawn of the field. At the beginning of the $20^{\text {th }}$ century, Bertrand Russell declared "that the fundamental concept in social science is Power, in the same sense in which Energy is the fundamental concept in physics" (Russell 1957, p. 10). Later on, Robert Dahl stated that "the concept of power is as ancient and ubiquitous as any that social theory can boast" (Dahl, 1957, p. 201). Norbert Elias claimed that "balances of power ... form an integral element of all human relationships" (Elias, 1978, p. 74), and Heinrich Popitz argued "that the bacillus power is inherent in all human relationships" (Popitz, 1992, p. 21) ${ }^{1}$. From the standpoint of systems theory, Niklas Luhmann conceived of power as a "symbolically generalized medium of communication" (Luhmann, 1979).

These quotations are a more or less random selection from the scientific pool of citations; similar statements could be found in nearly every theoretical paradigm of sociology. It is Max Weber to whom we owe the insight that power is not some kind of essence which adheres to the individual who is in possession of it, but a social "construction" emerging from intersubjective processes. Weber's genealogical studies on domination ${ }^{2}$ make clear that power is not a personal trait developed within a solipsistic sphere; it rather refers to an attribution that occurs within social relationships: one person (or a group of persons) ascribes certain traits to another person and this very circumstance enables the second person to assert his/her will. This attribution can rest on "objective" criteria, such as physical strength, yet the aspect of the phenomenon that is of primary sociological interest, is the way in which social patterns of perception, judgment, and behavior are built upon the basis of such criteria. These patterns cannot be attributed to particular social actors; instead they demonstrate the fundamental intersubjectivity of power. In short, sociology is less concerned with power, than it is with power relations. Norbert Elias put it as follows: "Power is not an amulet possessed by one person and not by another; it is a structural characteristic of human relationships" (Elias, 1978, p. 74).

This fundamental insight into the relational character of the phenomenon brings into focus the "between" of a social relationship, which requires (at

\footnotetext{
1 Translation by A.G. The German original reads: “daß der Bazillus Macht in allen menschlichen Beziehungen steckt".

2 In sub-volume II of the German version of Economy and Society.
} 
least) one person performing power and (at least) one other person subjected to this same power. Typically, this "between" is approached in one of two or three different ways: (1) one can seek a "direct" approach by focusing on societal elements of a structural nature which somehow determine the behavior of social actors - I will call this the "structuralistic" approach. It assumes that for any study on the nature of power it is crucial to know about such structures, and not so much about how people conceive of them. (2) One can analyze the "between" by studying its meaning for the persons involved - I will call this the "individualistic" approach. It assumes that intersubjective structures become apparent only in the behavior of individual social actors and therefore can only be explored by studying individual actions. The "individualistic" approach can be further subdivided into (a) the analysis of the person performing power and (b) the analysis of the person who is subjected to this power.

Having said this, I should add that the distinction between the two types of approaches focuses on the different starting points of the two paradigms, not on their results, which may be quite similar. Therefore they do not stand in a contradiction to each other. ${ }^{3}$ This paper is foremost concerned with the "individualistic" approach.

Given the fact that the conception of power as a relationship between at least two individuals owes considerably to Max Weber, his definition of power, which is still the most prominent one within the discipline, seems to be curiously one-sided, since it only looks at the performer of power: "Power is the probability that one actor within a social relationship will be in a position to carry out his own will despite resistance, regardless of the basis on which this probability rests" (Weber, 1968, p. 53). At first glance, Weber's focus may be perceived as being self-evident. Since he is concerned with power instead of powerlessness, then the concentration on the performer of power appears sound. Yet, if we take his insight seriously with regards to the relational character of power, his definition appears to be one-sided, as it largely ignores the perspective of the person who is exposed to power. One man's chance to dominate is another man's risk of being dominated. This aspect is somehow reflected in Weber's use of the term "resistance", but he does not elaborate on it.

Now, Weber's definitional bias did not mislead him into only studying the perspective of the performer of power, since he was clearly aware of the constitutive role played by those ascribing power to other persons. His exploration of this perspective, however, ends at the very point that his cognitive interest extends to - an interest marked by the popular dictum of David Hume:

3 It can be further added that the distinction is ideal-typical. Concrete sociological theories may therefore fall under both categories, like e.g. Elias's theory of figuration (1978). 
"Nothing appears more surprizing to those, who consider human affairs with a philosophical eye, than the easiness with which the many are governed by the few" (Hume, 2002, p. 29). Weber's sociological reflections can be read as an answer to the question inherent to Hume's statement: how is it that the few are allowed to govern the many? Accordingly, Weber's genealogical studies end at the point where this question is answered satisfactorily, and he is, therefore, not interested in the further consequences of powerlessness for those experiencing it in everyday life.

This bias becomes apparent in the fact that, when taking Weber's definition as a basis, powerlessness is a mere residual category which can only be defined ex negativo, that is, as the lacking of something else. Still the relation is an asymmetric one: someone who has power has the chance to manipulate his fellow men and he can make use of this power; on the other hand we cannot say that someone "has" powerlessness or that he "makes use" of his risk to be manipulated by others.

Another popular definition of power has been provided by Heinrich Popitz. According to him, power is "the ability to prevail over external forces" (Popitz, 1992, p. 22)4. I touch on this (not specifically sociological) definition, because it clearly hints at an anthropological background, which necessarily stands behind every theory of power - explicitly or implicitly. As most conceptions of power do, Popitz' formula conceives of man as "homo faber" (Scheler, 2009), as "animal laborans" (Arendt, 1959), who, through his work, appropriates his natural surroundings (Marx, 1961). In the same vein, starting from fundamental reflections on man's position in the world, Helmuth Plessner, in his Philosophical Anthropology, holds a general "conception of man as power" (Plessner, 1981, p. 189) . However, this notion of man's agency is by no means the exclusive intellectual property of philosophers, as is shown by the Christian idea of mankind subduing the earth (Genesis 1, 28).

Cultural comparison demonstrates that other religions have different notions of The Human Place in the Cosmos (Scheler, 2009), like e.g. Buddhism with its key concept of "dukkha" (usually translated as "suffering"), which describes a totally different attitude of mankind towards its earthly existence. In Buddhist teaching, man was not made in God's image as the designated ruler of the world; he is rather an incomplete being, subject to the cosmic forces, which he has to endure, not control. This broadening of the perspective makes clear that there is a counterpart to the Western conception of "homo

\footnotetext{
4 Translation by A.G. The German original reads: »das Vermögen, sich gegen fremde Kräfte durchzusetzen «.

5 Translation by A.G. The German original reads: »Konzeption des Menschen als Macht«.
} 
faber", namely the idea of man being passively exposed to the powers of his natural and cultural surroundings. In applying this fundamental insight to the context of the present subject matter, it becomes clear that where there is superordination there is, at the same time, subordination (Simmel, 1967, p. $181 \mathrm{ff}$.). ${ }^{6}$ Sure, this basic societal fact has not escaped the social theorists of the "individualistic" paradigm, however most of them share the approach of Weber and treat subordination as a mere explanatory factor for superordination, rather than as a topic for research in itself. Regarding what has been said about underlying anthropological assumptions, one might suspect that within the relevant terminology of this paradigm there is a disposition towards considering power relations from the point of view of the performer of power, not from the perspective of those subject to power.

Still, it would be unfair to blame the cited philosophers for a determination to that effect. Marx was certainly aware of the other side of the coin, of mankind as a "suffering, conditioned and limited creature, like animals and plants" (Marx, 1961, p. 69; original emphasis). Plessner also seemed aware of its importance, as he devoted a separate chapter of his book Macht und menschliche Natur (Power and Human Nature) to the issue "Ohnmacht und Berechenbarkeit des Menschen" ("Powerlessness and the Predictability of Mankind") (Plessner, 1981, p. $221 \mathrm{ff}$.). ${ }^{7}$ Thus, it is less philosophical theory itself, which is responsible for said bias of the "individualistic" paradigm, but more its reading by many sociologists. Maybe it is the historical heritage of sociology that is responsible for this reading - written history having always been the history of "great" men rather than the history of the powerless masses: "the history of political power ... is elevated into the history of the world", as Karl Popper observed in his Open Society (Popper, 2003, p. 299). Such a predisposition may be suitable for Weber's interest in world history ("Universalgeschichte"), yet it is hardly compatible with a sociology of everyday life, which became increasingly important over the course of the $20^{\text {th }}$ century.

In a certain sense the "individualistic" paradigm left the consideration of the subject of power's perspective more or less to the "structuralistic" analysis where the individual is principally conceived of as a function of societal structures, that is, as a "subject" in the original meaning of the Latin word. Arguably the most prominent theory within this school of thought is Michel Foucault's conception of subjectivism in which he regards the subject as the outcome of historical practices of discourse (Foucault, 1970). However, it is

\footnotetext{
6 This idea can be found in, arguably, the most influential philosophical theory of power, that of Thomas Hobbes (1960). He clearly pointed out that the installation of the omnipotent Leviathan presupposes the abandonment of power by each individual citizen.

7 Translation of the German titles by A.G.
} 
quite obvious that this "structuralistic" approach cannot compensate for the shortcomings within the "individualistic" paradigm, since it gives no account of the subjective meaning of the analyzed structures, that is, the meaning it has for the individuals involved.

Against the background of this finding, this essay concerns itself with a theory rarely used in connection with the issue of power, namely Alfred Schutz's theory of the life-world. Amongst social scientists Schutz has become known for trying to create a philosophical foundation for Max Weber's Interpretive Sociology. To this end, he adopted subject-oriented philosophical theories, in particular the one of Edmund Husserl. His reference to a philosophy of consciousness has exposed Schutz's social theory to a frequent criticism: it has often been cited as lacking the ability to consider power relations. Critics claim that the homunculi who populate the Schutzian life-world would negotiate the definition of their common situation on an equal footing in some kind of non-coercive universe of discourse. In the same vein, Schutz's method of constructing a social theory by starting with the reflections of the solitary individual and adding the social layers bit by bit (Schutz, 1967) has been accused of being deceptive, since it allegedly ignores the fact of the individual's ubiquitous interlacement within social structures of power.

In light of this critique of Schutz, it may seem peculiar to consult, of all things, his work in order to improve upon the sociological reflection on phenomena of power. I do so, because I think that there are certain concepts introduced by Schutz, which are fundamentally capable of responding to the deficiency described above. The concepts I have in mind originate from Schutz's theory of relevance, which is commonly, and justifiably so, seen as part of (or as the phenomenological foundation of) a sociology of knowledge, since it describes the way in which an individual interprets his (social) surroundings. The theory of relevance is therefore integrated into the chapter entitled "Knowledge of the Life-World" in The Structures of the Life-World (Schutz and Luckmann, 1974, p. 99ff.). In spite of this original intention, the theory of relevance provides theoretical instruments which can be of original value for the analysis of power. Especially Schutz's differentiation between "intrinsic" and "imposed" relevances ${ }^{8}$ establishes a useful concept in this respect. Thus, in the following I will discuss these concepts with reference to their adequacy for overcoming the one-sidedness of the "individualistic" paradigm. In order to do so it is essential to briefly introduce Schutz's theory of relevance.

8 The grammatically incorrect plural "relevances" is built in accordance with Schutz, who, even though writing in English, obviously contemplated the subject matter while having the German concepts in mind. In his native tongue the plural "Relevanzen" is unproblematic. 


\section{Alfred Schutz's theory of relevance}

By means of this theory Schutz tries to explain, in which way the ascription of relevance is constituted within the consciousness of an individual: how does it come about that a certain topic attracts attention, which aspects of the topic are recognized as being significant, which parts of the individual's stock of knowledge are used for interpretation, and which motives exert an influence on this process? According to these questions, Schutz differentiates between three ideal types of relevance: (1) topical relevances, (2) interpretative relevances, subdivided into (a) those of the topic and (b) those of the stock of knowledge, and (3) motivational relevances.

(1) Topical relevance determines toward which topic an individual directs his or her conscious intentionality. Generally speaking, topics become relevant to us, when they stand out against a background of familiar things: in the streets of Kabul a woman covered in a burqa does not attract attention - in the streets of Tucson, Arizona, however, she would. Such, topical relevances emerge when things become questionable and this can happen for certain specific reasons, which I will discuss later.

(2) Interpretative relevance of the topic determines which aspects of the thematic object are considered relevant for interpretation. Usually not every aspect of an object is relevant for its understanding. If I have a problem with my computer and call the telephone hotline, the consultant will not ask me about the computer's color, but rather about technical details like the installed systems software or something similar. In the same way, not every part of my stock of knowledge is relevant for interpreting a single topic. My knowledge about German football players is to no avail when it comes to writing a scientific paper about the phenomenon of power. The interpretative relevance of the stock of knowledge determines which parts of the latter are used for interpretation. This applies to those of our previous experiences which appear to have some sort of similarity to the new topic and thus provide a type under which the unfamiliar object may be subsumed. ${ }^{9}$

(3) Motivational relevance refers to the "adequate ground" (Weber, 1968, p. 11) of human behavior. Schutz generally adopts Weber's conception of motive, yet he makes a differentiation that goes beyond Weber:

First there appears to me, as the meaningful ground of my behavior, a series of future events whose occurrence I propose to bring about. I am orienting my behavior to this end. But there is a second sense in

\footnotetext{
9 Schutz borrows the concept of type, which is essential for his thinking in general, from the phenomenology of Husserl (Schutz, 1966).
} 
which I sometimes speak of the meaningful ground of my behavior. Here I refer to those past experiences of mine which have led me to behave as I do (Schutz, 1967, p. 28).

Schutz calls the former "in-order-to-motives", and the latter "becauseof-motives". In-order-to-motives principally refer to because-of-motives since projects of action, which are oriented toward the future, always build on the basis of dispositions, which lie in the past. For instance, when I eat ice-cream I do so because in the past equivalent actions proved to be positive experiences, and I do so in order to get this sensation again.

As man is a creature of habit (Gehlen, 1988), relevances are not formed anew in each new situation. Relevances which have stood the test of time become a kind of "recipe". If the interpretation of a situation fulfills my given pragmatic objective, the according relevances become part of my stock of knowledge - this knowledge then "sediments", according to Schutz. Whenever I encounter a similar situation, I can draw on this knowledge in order to cope with the circumstances, and every time I succeed by applying formerly used relevances these become more firmly rooted. Thus, I develop typical relevances for typical situations: the thematic horizon is pre-established, I know which aspects I have to consider and which I can ignore, I know which patterns of interpretation are adequate, and I also know if certain motives are appropriate or not. In this way, systems of relevance emerge which are relatively stable. Certainly, when coming into a situation which is genuinely new, my adhoc-interpretation might fail, but in the recurring situations of everyday life my "recipe" usually does the trick. And since such daily circumstances are typically the same for social groups, milieus, or even whole societies, systems of relevance are shared intersubjectively: "the world taken for granted by the in-group is a world of a common situation within which common problems emerge within a common horizon, problems requiring typical solutions by typical means for bringing about typical ends" (Schutz, 1964a, p. 236).

The possible significance of the theory of relevance for the analysis of phenomena of power becomes clear when we look at another basic differentiation of Schutz. He subdivides all three types of relevance into the categories of "intrinsic" and "imposed" relevances, thereby taking into account the idea that relevances can be experienced as voluntary or involuntary (analogously he sometimes speaks of "free" and "bound" relevances). Schutz applies this differentiation to his three ideal types as follows:

(1) An "intrinsic" topical relevance originates when an individual voluntarily divides his field of consciousness into a thematic nucleus and a 
thematic horizon, for instance when changing the topic of investigation or engaging in the further development of an existing topic. In contrast, an "imposed" topical relevance is caused by an interruption of either of the idealizations of the life-world, that is, the idealization of "I-can-do-it-again" or of "and so on". ${ }^{10}$ Such an interruption forces the individual to deal with a thematic object that he would not have dealt with of his own free will.

(2) An "intrinsic" interpretative relevance originates when there is an interpretation problem, that is, when the new topic does not adequately conform to the existing knowledge at hand and an adequate interpretation cannot be reached. If, on the other hand, the new topic fits exactly into the patterns of the ready-made stock of knowledge, then the interpretation happens as some kind of routine, quasi-automatically, in which case Schutz speaks of an "imposed" interpretative relevance.

(3) Finally, in the case of motivational relevance the difference between "intrinsic" and "imposed" relevances is the same as that between in-order-to and because-of motives. Schutz principally defines the former as "intrinsic" motives, as they are projected into the future, whereas the latter are generally said to be "imposed" motives, as they are determined by dispositions which lie in the past, like, for instance, character traits.

\section{Relevance and power}

As has already been stated, my thesis claims that the introduction of the differentiation between "intrinsic" and "imposed" relevances into a theory of power may help to correct the above mentioned bias within the "individualistic" paradigm. In amplifying the considerations of Weber, Schutz's distinction shows us that powerlessness is not simply the absence of power (or, modifying Weber's definition: the improbability of carrying out one's own will within a social relationship), but it is instead to act in accordance with "imposed" relevances - be them of a topical, interpretative, or motivational nature. Schutz himself makes similar use of his theory in his essay "Equality and the Meaning Structure of the Social World" (1964a), in which he applies his theoretical concepts to various empirical phenomena, like e.g. racial discrimination. He shows that the self-interpretation of an in-group must necessarily differ from the interpretation of this very group by any out-group, because of differing systems of relevance. Initially, being dark-skinned may not be of excessively high relevance for a US-citizen of Afro-American origin, but when living in a society where the color of one's skin serves as a criterion for discrimination and consequently for the unequal treatment of social groups, maybe even

\footnotetext{
${ }^{10}$ For these idealizations cf. Husserl, 1969, § 74.
} 
before law, then this subjectively less important feature becomes highly relevant for him. The "objective" (in the Weberian sense) interpretation by the out-group superposes itself on his self-interpretation, it forces him to adopt certain relevances and to behave in accordance with them; to some extent it even constitutes his belonging to the in-group in the first place. Schutz's theory of relevance opens up a theoretical approach that goes beyond the rather limited statement that such a person is subject to prejudice. It provides a differentiated tool for empirical analysis by considering the perspective of powerlessness as experienced by the individuals concerned.

Furthermore, its orientation towards a sociology of knowledge allows for a differentiated description of the use of definitional power, that is, the power of someone who is able to provide authoritative definitions of situations. In every society such definitions (which are of special importance within media democracies) are conceded to certain persons like incumbents, experts, religious leaders, etc. Using Schutz's terminology, such persons declare certain systems of relevance, including topical, interpretative, and motivational relevances, as binding. A person, who can successfully do this and who is able to provide a socially approved definition of the situation, has power, as this person is to some degree able to influence the resulting action, since different definitions of the situation suggest different actions. For example, when a politician declares that the nation is acutely threatened by terrorists, he puts national security high on the political agenda, thereby repressing other topical relevances. When he states that said terrorists are driven by a murderous, fundamentalist ideology, he uses a certain pattern of interpretation, thereby excluding others. And when he claims that the "war on terror" has to be fought with regard to the global installation of democracy, he favors a particular motive, thereby neglecting others. If his statements are combined with a political will (which we can generally assume), they are part of an exercise of power. The example shows that Schutz's typification allows us to precisely analyze the performance of definitional power, because it makes it possible to identify the exact "locus" of this performance: is it the limiting of the thematic horizon, the exclusion of certain interpretational patterns, or the preference for a particular motive? ${ }^{11}$

Surely, this kind of performance of power only works if the definition given by the particular person is commonly accepted. Schutz basically

11 Weber's famous study on protestant ethics (Weber 2002) can be used as an illustration: the seminal influence of Luther's and Calvin's teachings was that it instructed their believers to consider a certain part of their lives as the most important topical relevance (profession), to interpret this part in accordance with a certain interpretational relevance (the doctrine of predestination), and to strive after the same motivational relevance (the quest for salvation). 
provides two explanations for how such common acceptance is to be achieved: the social derivation of knowledge and its social acceptance, which point to the fundamental concepts of the "sedimentation of knowledge" (Schutz, $1967, \S 14$ ) and the "reciprocity of perspectives" (Schutz, 1962, p. 11ff.). His phenomenologically oriented reflections open up the way for empirical studies. Berger and Luckmann's famous book on The Social Construction of Reality (Berger and Luckmann, 1967) is a prominent example of an effort to build a social theory on the basis of Schutz's concepts.

The two above delineated aspects - the allowance for the perspective of the powerless and a detailed description of the functionality of definitional power - illustrate the principal usefulness of Schutz's theory of relevance for certain problems within the context of power analysis. However, the application of this theory also poses a problem, which I would like to introduce by going back to Weber's definition of power. Its English translation has already been cited above, yet it is important to note that this translation distorts the primary intent of the German original, as the formulation "despite resistance" insinuates that the existence of a resisting will is a presupposition when we speak of power. Yet, Weber also speaks of power in cases where there is no resisting will. In the German original it says "auch gegen Widerstreben" - "even despite resistance" (emphasis added), which allows one to also read what is implied: not only against opposition.

So, according to Weber, power may also be performed in cases where there is no resisting will on the part of the person it is acted upon, that is, when the latter does not experience the power performed over him as coercion. Paraphrasing this insight using Schutz's terminology we can state that power is not only performed by imposing one's own relevances on another person against her will, that is, when two conflicting systems of relevance exist. Power can also be performed by defining one's own relevances as common ones, that is, when only one system of relevance exists and the according projects of action are experienced by every person involved as if they would emanate from his own free will. Now, this finding brings us into some trouble, inasmuch as it questions the thesis expressed above, namely the principal usefulness of the Schutzian distinction between "imposed" and "intrinsic" relevances for the purposes of power analysis: if behavior based on relevances that are subjectively experienced as "intrinsic" can be "bound" as well, then is the differentiation of any avail at all?

This is a fundamental question to be dealt with when suggesting that Schutz's concepts can be used for an improved analysis of power. The following remarks intend to show how such integration may work. 


\section{Integration}

With reference to said intention, the main problem resulted from our focusing on the point of view of those subject to power (according to our initial aim of inquiry). Thus it seemed that the answer to the question of whether a sociologist is confronted with a case where power is performed or not depends on whether the social actors experience the according relevances as "imposed" or "free". Weber's definition of power, as quoted above, demonstrates the dubiety of such a criterion for sociological purposes, because it runs the risk of neglecting that particular sort of "power which generates deliberate, consenting willingness to comply" (Popitz, 1992, p. 28) ${ }^{12}$. Schutz himself was aware of this problem: "The concept of imposed relevances applied to social relationships does not contain any reference to the problem of whether or not the imposition involved is accepted by the partner", he writes in his essay "The Well-informed Citizen" (1964b, p. 128). Consequently, one has to look for a different criterion for identifying power. It is obvious to search for this criterion by reflecting the perspective of those performing power, like in Weber's definition: the chance to carry out one's own will within a social relationship.

At this point, the question arises whether the performance of power is always experienced as oppression by the social counterpart. Another passage from Schutz's essay, in which he reflects on the relationship of the fictitious persons Peter and Paul, seems to answer positively: "In so far as Peter is the object of Paul's action and has to take into account Paul's specific goals which he, Peter, does not share, Paul's intrinsic relevances are to Peter imposed relevances and vice versa" (ibid.). This statement suggests that we can identify the imposed relevances of those subject to power by recognizing the intrinsic relevances of those performing power, since the concepts correspond each other. However, this suggestion presupposes that we can exclude in the forerun those relevances, which are intrinsic to Peter and Paul. But there is a basic bias when we confine ourselves to the description of the ego's consciousness: ${ }^{13}$ if we accept the plausible assumption that the actor is primarily aware of his intrinsic in-order-to motives whereas he tends to lose sight of his imposed because-ofmotives (Schutz and Luckmann, 1974, 219f.; Schutz, 1967, p. 130f.), we must conclude that actors live their lives with a chronic over-estimation of their freedom of action. As sociologists, we should be rather skeptical about the

12 Translation by A.G. The German original reads: "eine Macht, die willentliche, einwilligende Folgebereitschaft erzeugt."

${ }^{13}$ For the purpose of illustration, in the following I will focus on motivational relevances only; but the argument also applies to the other types of relevance. 
perception of such individuals, especially when reflecting on power. Moreover, the proposition of said correspondence can be contested with hindsight to those cases where the intrinsic relevances of Peter are irrelevant to Paul, which does not seem uncommon especially in relationships characterized by a high degree of anonymity.

For the scientist, the solution must be to move on from the subjective perspectives of the afflicted persons and to turn towards the objective perspective of the detached observer. Within the context of Interpretive Sociology this does not mean to ignore the subjective views, but in the contrary to hermeneutically reconstruct them and to transpose them into a different system of relevances - to create a "second-order-construct" out of a "first-order-construct" in the terms of Schutz. ${ }^{14}$ This detachment from the subjective meaning opens the "individualistic" paradigm for the consideration of structural moments.

Now, Schutz's terminology creates certain problems when we try to use the theory of relevance in such a way for an empirical description of social reality - or to put it differently: when we try to make sociological use of the phenomenological concept of relevance. The first problem is explicitly stated in The Structures of the Life-world:

In short, plans are embedded in plan hierarchies, which finally refer to the limits of the human situation in the life-world. This means that either immediately, or at least mediately, all conduct can be ordered in contexts of 'free' motivational relevance. Vice versa, however, in principle every act and all conduct have a 'history'. A 'first' project is [...] unimaginable. Fundamentally, all conduct and every act can be understood in contexts of 'bound' motivational relevance (Schütz and Luckmann, 1974, p. 222f.) ${ }^{15}$

This shows that the answer to the question whether a concrete action is "intrinsic" or "imposed" depends on the particular perspective: if I look at the previous because-of-motives of an individual, the action will appear to be imposed, if I look at the projected in-order-to motives the action appears to be intrinsic. Clearly such indecisiveness is not very helpful if one wants to make an empirical statement about the actual compulsory framework of a particular action or behavior.

The second problem is one that Schutz was not aware of, as far as I can see. The a priori definition of because-of-motives as "imposed" and of

14 The distinction between "first-order" and "second-order"-constructs is explicated in Schutz 1962: $5 \mathrm{ff}$.

15 This phrasing is reminiscent of Kant's Third Antinomy of Pure Reason (Kant, 1996, p. B 473ff.). 
in-order-to-motives as "intrinsic" violates the "postulate of adequacy" ${ }^{16}$ For instance, when Schutz states that from a psychological point of view the particular complex of because-of-motives of an individual can be described as the "character" of this person (Schutz, 1970, p. 66), this would mean that our character is something which is "imposed" upon us. This is not the way people think of their personality in everyday life, at least not exclusively. Furthermore, when Schutz says that in-order-to-motives are principally "intrinsic" this conflicts with our common sense thinking. Imagine for example a robbery where the victim hands over his money to a criminal in order to not get shot. In this way, the "second-order-constructs" of the theory of relevance stand in contradiction to the "first-order-constructs" of our daily experience.

I think the reason that Schutz violates the postulate of adequacy lies in the fact that our common sense emphasizes one aspect of our actions that is widely neglected in the theory of relevance, namely social coercion. This aspect of the theory only gets explicitly mentioned in The Structures of the Life-World, that is, in the further development of Schutz's theory by Thomas Luckmann after Schutz's death, but not in the original draft itself. ${ }^{17}$ And it is significant for Luckmann's treatment of social coercion that it has no systematic place in the theory of relevance, it only gets mentioned sporadically throughout his text.

This specific shortcoming of the theory of relevance - or within the given context: of an application of this theory to social phenomena of power - can be explained by contemplating Schutz's basic approach. In his Reflections on the Problem of Relevance he consciously makes use of the methodological "fiction that this problem can be studied for a supposedly isolated mind without any reference to sociality" (Schutz, 1970, p. 134). Like in his book The Phenomenology of the Social World (1967) he uses a method of analysis which is the exact opposite of the phenomenological method of epoché: he begins with reflections about the constitutive acts of the ego's consciousness and later seeks to broaden his scope of analysis by looking at the alter ego as well. Now, the problem is that Schutz never concluded his studies by adding the latter analysis; his theory of relevance remains a fragment.

Choosing the "isolated individual experienc[ing] the world of nature disconnected from his fellowmen" (Schutz, 1970, p. 73) as a starting point for

\footnotetext{
16 "Each term in a scientific model of human action must be constructed in such a way that a human act performed within the life-world by an individual actor in the way indicated by the typical construct would be understandable for the actor himself as well as for his fellow-men in terms of common-sense interpretation of everyday life" (Schutz, 1962, p. 44).

${ }^{17}$ In the same way, the excerpts from "The Well-informed Citizen" quoted above are not part of the original theoretical draft but instead applications of some of its concepts. Therefore they do not provide counterevidence to the statement that social coercion is neglected in the theory of relevance.
} 
reflection means to delay the consideration of social coercion to a later stage, and so Schutz works with a definition of "imposed" and "intrinsic" relevances which is by necessity preliminary. Summarizing Schutz's arguments one can say that "imposed" relevances are relevances which lie either in the past or in a latent, subconscious layer of the individual's mind and therefore beyond the rational influence of the actor. On the other hand, "intrinsic" relevances are such relevances which refer to future actions and which the individual actor is aware of. With this adumbration of the border between "imposed" and "intrinsic" relevances Schutz certainly makes a valid argument. The criteria of time and latency definitely play an important role in the problem under scrutiny: the force of habit can hardly be overestimated, and it seems sound to describe a relevance that the actor is not aware of as "bound". Nevertheless, because of the volitional narrowness of his methodological approach Schutz only tells half the story. By focusing on the solitary individual, he sticks to the question of inner freedom and neglects any consideration of outer freedom, which can only be analyzed by taking the social context into account.

In order to overcome the described deficits, the perspective needs to be broadened by analyzing not only "the isolated individual's experiences" (Schutz, 1970, p. 52), but also the experiences of the socialized individual. Schutz intended to take this next step himself, so it can be regarded as a completion of his theory of relevance. Yet, it would be erroneous to simply add social coercion as a third type of way in which relevances can be imposed, alongside the phenomena of latency and time as reflected by Schutz. In fact, the objective must be to cross-reference the different aspects. Especially with regard to the performance of definitional power Schutz's differentiation between "monothetic" and "polythetic" reconstruction provides a promising tool for this kind of approach. ${ }^{18}$

\section{Conclusion}

The previous discussion of the difficulty of a direct application of Schutz's concepts to a sociological study on power makes clear that the theory of relevance cannot serve as a substitution, but only as a selective amendment to existing theories on the subject. Such an amendment is conceivable despite the fact that this theory in its posthumous form is not a theory of power - not even a social theory as such.

\footnotetext{
${ }^{18}$ Yet his tendency to identify "monothetic" reconstruction with belief in another person's authority (Schutz, 1970, p. 84f.) is too simple and needs further clarification, as Ronald Cox rightly points out (Cox, 1978, p. 138ff.).
} 
This paper argued that an extension of Schutz's theory of relevance can be useful for a sociology of power which intends to broaden its considerations to the point of view of those subject to power, thereby overcoming the deficit diagnosed in chapter one. For this purpose, the concept of "imposed relevances" is of fundamental value. Although the according orientation alone cannot be expedient for an analysis of the phenomenon (the same goes for the exclusive focusing on the subjective view of the performer of power), its involvement is indispensable with regard to a comprehensive scientific coverage of the topic. And it carries the general caveat regarding a reification of "objective" elements over to the sociology of power, by reminding us that structures of power only gain significance through their subjective interpretation by social actors.

In general, accounting for those, who are exposed to the power of others, can be seen as a "democratization" of the sociology of power, inasmuch as it considers the perspective of the masses as in contradistinction to the "power elite" (Mills, 1978). This goes hand in hand with a turn towards the consideration of everyday life, where we all regularly have to come to terms with relevances imposed on us by others. Such problems are common topics of sociological research practice, e.g. within the sociology of work or migration, yet an adequate reflection in terms of the theoretical conceptualizing of power relations is still lacking. If the "will to power" (Nietzsche) is in fact part of the human condition, then there must be people exposed to power in every given society at any time, and sociology is constrained to not ignore this group.

In addition, Schutz's thoughts remind us that the fundamental powerfulness of man, described by thinkers like Helmuth Plessner, not only refers to the active manipulation of his (natural) environment, but also to the interpretive construction of his (cultural) surrounding. The ideal typical differentiation between topical, interpretative, and motivational relevance allows us to precisely analyze this form of definitional power. Schutz himself, when applying his general theory of relevance to social relations, seemed to conceive of its epistemic orientation as some kind of limitation. In his aforementioned essay on "Equality" he remarks that racial discrimination can only work if there is an asymmetric allocation of political power, enabling the out-group to impose its interpretation on the in-group. Thus it seems that Schutz would have thought of the application of his concepts within a sociological research on power as a mere means of describing certain consequences of existing distributions of political power, without being able to provide a basic explanation about the phenomenon of power. However, I think that we need not share his skepticism, since we can easily reverse Schutz's argument: political power always works within an interpretational framework, a particular view 
of society and its structure. And on that note we can say that he who has definitional power is principally able to determine the boundaries of political power. Heinrich Popitz rightly conceives of definitional power (he calls it "authoritative power"; 1992, p. 29) as one of four anthropological basic forms of power (1992, p. 22ff.), and this is why sociological research on power should not abandon the input of a sociology of knowledge. Alfred Schutz's theory of relevance bears precious insights in this respect.

\section{References}

ARENDT, Hannah. The human condition. Chicago, Ill.: Univ. of Chicago Press, 1959.

BERGER, Peter L.; LUCKMANN, Thomas. The social construction of reality: a treatise in the sociology of knowledge. New York: Doubleday, 1967.

COX, Ronald. Schutz's theory of relevance: a phenomenological critique. The Hague: Nijhoff, 1978.

DAHL, Robert A. The concept of power. Behavioral Science, v. 2, n. 3, p. 201-215, July 1957.

ELIAS, Norbert. What is sociology? London: Hutchinson, 1978.

FOUCAULT, Michel. The order of things: an archaeology of the human sciences. New York: Random House, 1970.

GEHLEN, Arnold. Man: his nature and place in the world. New York: Columbia Univ. Press, 1988.

HOBBES, Thomas. Leviathan: or the matter, forme and power of a commonwealth ecclesiastical and civil. Oxford: Blackwell, 1960.

HUME, David. Essays and treatises on several subjects. Bristol: Thoemmes Press, 2002. Vol. 1: Essays, Moral, Political, and Literary.

HUSSERL, Edmund. Formal and transcendental logic. The Hague: Nijhoff, 1969.

KANT, Immanuel. Critique of pure reason. Indianapolis: Hackett Publ., 1996.

LUHMANN, Niklas. Trust and power: two works. Chichester: Wiley, 1979.

MARX, Karl. Economic and philosophic manuscripts of 1844. Moscow: Foreign Languages Publ. House, 1961.

MILLS, Charles W. The power elite. Oxford: Oxford Univ. Press, 1978.

PLESSNER, Helmuth. Macht und menschliche Natur (Gesammelte Schriften V). Frankfurt, Main: Suhrkamp, 1981.

POPITZ, Heinrich. Phänomene der Macht. Tübingen: Mohr, 1992.

POPPER, Karl. The open society and its enemies. London: Routledge, 2003. Vol. 2.

RUSSELL, Bertrand. Power: a new social analysis. London: Allen \& Unwin, 1957.

SCHELER, Max. The human place in the cosmos. Evanston: Northwestern Univ. Press, 2009. 
SCHUTZ, Alfred. Common-sense and scientific interpretation of human action. In: Collected Papers I. The problem of social reality. The Hague: Nijhoff, 1962. p. 3-47.

SCHUTZ, Alfred. Equality and the meaning structure of the social world. In: Collected Papers II. Studies in social theory. The Hague: Nijhoff, 1964a. p. 226-273.

SCHUTZ, Alfred. The well-informed citizen: an essay on the social distribution of knowledge. In: Collected Papers II. Studies in social theory. The Hague: Nijhoff, 1964b. p. 120-134.

SCHUTZ, Alfred. Type and eidos in Husserl's late philosophy. In: Collected Papers III. Studies in phenomenological philosophy. The Hague: Nijhoff, 1966. p. 92-115.

SCHUTZ, Alfred. The phenomenology of the social world. Evanston, Ill.: Northwestern Univ. Press, 1967.

SCHUTZ, Alfred. Reflections on the problem of relevance, New Haven/London: Yale Univ. Press, 1970.

SCHUTZ, Alfred; LUCKMANN, Thomas. The structures of the life-world. London: Heinemann, 1974. Vol. I.

SIMMEL, Georg. The sociology of Georg Simmel. New York: Kurt H. Wolff/Free Press, 1967.

WEBER, Max. Economy and society. An outline of interpretive sociology. Berkeley: Univ. of California Press, 1968.

WEBER, Max. The protestant ethic and the spirit of capitalism. Los Angeles: Roxbury, 2002.

Recebido em: 29/05/2011

Aprovado em: 29/06/2011 